\title{
Norcantharidin-induced Apoptosis of AGS Human Gastric Cancer Cells Through Reactive Oxygen Species Production, and Caspase- and Mitochondria-dependent Signaling Pathways
}

\author{
LI-CHENG ZHENG ${ }^{1 \#}$, MEI-DUE YANG ${ }^{2,3,4 \#}$, CHAO-LIN KUO ${ }^{5}$, CHIA-HSIN LIN ${ }^{5}$, MING-JEN FAN ${ }^{6}$, \\ YU-CHENG CHOU ${ }^{7}$, HSU-FENG LU ${ }^{8}$, WEN-WEN HUANG ${ }^{1}$, SHU-FEN PENG ${ }^{1 *}$ and JING-GUNG CHUNG ${ }^{1,6^{*}}$ \\ Departments of ${ }^{1}$ Biological Science and Technology, and ${ }^{5}$ Chinese Pharmaceutical Sciences and \\ Chinese Medicine Resources, China Medical University, Taichung, Taiwan, R.O.C.; \\ Departments of ${ }^{2}$ Surgery and ${ }^{3}$ Clinical Nutrition, and ${ }^{4}$ Terry Fox Cancer Research Laboratory, \\ China Medical University Hospital, Taichung, Taiwan, R.O.C.; \\ ${ }^{6}$ Department of Biotechnology, Asia University, Taichung, Taiwan, R.O.C.; \\ ${ }^{7}$ Division of Neurosurgical Oncology, Neurological Institute, \\ Taichung Veterans General Hospital, Taichung, Taiwan, R.O.C.; \\ ${ }^{8}$ Department of Clinical Pathology, Cheng Hsin General Hospital, Taipei, Taiwan, R.O.C.
}

\begin{abstract}
Norcantharidin (NCTD) was purified from mylabris, the dried body of the Chinese blister beetle. NCTD has been shown to exhibit anticancer activities in many human cancer cell lines, but there are no reports to show whether it induces apoptosis of human gastric cancer cells. Therefore, in the present study, we investigated NCTDinduced cell death and associated protein expression in human gastric cancer AGS cells in vitro. Cell morphological changes, viability and cell-cycle distribution were examined and analyzed by phase-contrast microscopy and flow cytometric assays. Flow cytometry was also used to measure the levels of reactive oxygen species (ROS), $\mathrm{Ca}^{2+}$, mitochondrial membrane potential $\left(\Psi_{m}\right)$ and activity of caspases. The results indicated that NCTD induced cell morphological changes, reduced total viable cell number and induced $G_{0} / G_{1}$ phase arrest. NCTD also increased ROS production and reduced the $\Psi_{m}$ and increased caspase-9
\end{abstract}

\footnotetext{
\#*These Authors contributed equally to this work.

Correspondence to: Jing-Gung Chung, Ph. D., Department of Biological Science and Technology, China Medical University, No 91, Hsueh-Shih Road, Taichung, Taiwan, R.O.C. Tel: +886 422053366 ext 8000, Fax: +886 422053764, e-mail: jgchung@mail.cmu.edu.tw and Shu-Fen Peng, Department of Biological Science and Technology, China Medical University, No 91, Hsueh-Shih Road, Taichung, Taiwan, R.O.C. Tel: +886 422053366 ext 2506, Fax: +886 422071507, e-mail: sfpeng@mail.cmu.edu.tw
}

Key Words: Norcantharidin, mitochondria, reactive oxygen species, ROS, apoptosis, AGS human gastric cancer cells. activity in AGS cells. Western blotting also found that NCTD increased the pro-apoptotic proteins such as BCL2-associated $X$ protein $(B A X)$ and $B H 3$ interacting-domain death agonist (BID) and increased the release of cytochrome $c$, apoptosis inducing factor (AIF) and endonuclease $G$ (Endo $G$ ) release from mitochondria in AGS cells. NCTD also significantly increased the expression of active forms of caspase-3 and -8 and -9 and reduced the expression of caspase-4 and -12 in AGS cells. Based on these observations, we suggest that NCTD-induced apoptotic cell death may be through mitochondria- and caspase-dependent pathways.

Gastric cancer is the seventh most common cancer in Taiwan and 10 individuals per 100,000 die annually from gastric cancer based on the 2014 report from the Department of Health (Taiwan) (1). Risk factors include genetic factors, lifestyle and environmental toxic chemicals $(2,3)$. Currently, primary surgery, radiation therapy, chemotherapy or the combination of chemo- and radiotherapy are the major treatment options for patients with gastric cancer.

Apoptosis, a type of programmed cell death, plays a critical role in a wide variety of physiological processes during fetal development and in adult tissues (4). Cell apoptotic features include cell shrinkage, nuclear collapse, membrane blebbing, and DNA fragmentation $(5,6)$. Thus, this process has been the most frequently taken as a major pathway for chemotherapeutics to combat cancer cells. It is well documented that cell apoptosis is mediated through extrinsically and intrinsically mediated pathways. The extrinsically mediated pathway is triggered through activation of cell surface ligand-gated death receptors and the intrinsically 
medated pathway involves the mitochondria, which are disrupted by cell stress (6) followed by cytochrome $c$ release thereby inducing apoptosome formation and activating caspases causing cell apoptosis $(7,8)$.

One strategy for anticancer function of drugs is to trigger tumor cell apoptosis in patients (9). Numerous experiments have been undertaken to find novel compound from natural products to achieve this in treating patients with gastric cancer.

Norcantharidin (NCTD) is a bioactive compound and lowtoxicity analog of the active anticancer compound cantharidin, purified from mylabris, the dried body of the Chinese blister beetle (10). Much evidence has demonstrated that NCTD exerts antitumor activities against hepatoma (11), medulloblastoma (12), bladder carcinoma (13), myeloid leukemia (14), melanoma (15) and gallbladder carcinoma (16) cells. NCTD induced DU145 cell apoptosis through reactive oxygen species (ROS)-mediated mitochondrial dysfunction and ATP depletion (10) and may exert its anticancer activity through the suppression of the RAF kinase/mitogen-activated protein kinase kinase/extracellular signal-regulated kinases (RAF/MEK/ERK) pathway (17). NCTD has anti-vasculogenic mimicry activity against human gallbladder cancer possibly via blocking the ephrin type A receptor $2 /$ focal adhesion kinase/paxillin signaling pathway (18). NCTD inhibits lymphangiogenesis by down-regulating the expression of vascular endothelial growth factor-C (VEGFC) and VEGFD (19). Recently, it was indicated that the induction of apoptosis of human hepatocellular carcinoma HepG2 and SMMC-7721 cells with treatment of ABT-737 (an antagonist of B-cell lymphoma 2, BCL2) combined with NCTD for $48 \mathrm{~h}$ was greater than that of both ABT-737 and NCTD alone (20).

Although numerous studies have shown that NCTD induced cell death in many human cancer cell lines, the anticancer activity of NCTD on human gastric cancer cells in vitro, and its underlying mechanisms, have not been fully investigated. Therefore, in the present study, we investigated the efficacy of NCTD on AGS gastric cancer cells and attempted to elucidate detailed mechanisms of anticancer activity.

\section{Materials and Methods}

Chemicals and reagents. NCTD of 99\% purity, 6-diamidine-2 phenylindole (DAPI), dimethyl sulfoxide (DMSO), propidium iodide (PI) and trypsin-EDTA were obtained from Sigma Chemical Co. (St. Louis, MO, USA). RPMI-1640 medium, fetal bovine serum (FBS), Lglutamine and penicillin-streptomycin were purchased from GIBCO $^{\circledR} /$ Invitrogen Life Technologies (Carlsbad, CA, USA). Primary antibody against caspase-3, -7, -8, -9, p21 ${ }^{\mathrm{CLP} 1 / \mathrm{WAF} 1}$ (p21), p27KIP1 (p27), apoptosis inducing factor (AIF), Bcl2-associated $\mathrm{X}$ protein (BAX), BH3 interacting-domain death agonist (BID) and BCL2 were purchased from Santa Cruz Biotechnology, Inc. (Dallas, TX, USA) and those against poly (ADP-ribose) polymerase (PARP), cytochrome $c$, endonuclease $\mathrm{G}$ (Endo $\mathrm{G})$, second mitochondrial-derived activator of caspase (SMAC), X chromosome-linked inhibitor of apoptosis protein (XIAP), p53, Fas receptor (FAS), Fas ligand (FASL), death receptor 4 (DR4), death receptor 5 (DR5), tumor necrosis factor $\alpha$ (TNF $\alpha$ ), TNF-related apoptosis-inducing ligand (TRAIL), glucoseregulated protein 78 (GRP78), cyclin D, cyclin-dependent kinase 6 (CDK6), caspase-4, caspase-12, calpain-1 and peroxidase-conjugated secondary antibodies were purchased from Cell Signaling Technology, Inc. (Beverly, MA, USA). NTCD was dissolved in DMSO. Cell culture grade DMSO was used for vehicle at $0.1 \%$.

Cell culture. The human gastric cancer AGS cell line was obtained from the Food Industry Research and Development Institute (Hsinchu, Taiwan, ROC). AGS cells were grown in RPMI-1640 medium supplemented with $10 \%$ heat inactivated FBS and antibiotics (100 units $/ \mathrm{ml}$ penicillin, $100 \mu \mathrm{g} / \mathrm{ml}$ streptomycin, and $2 \mathrm{mM}$ glutamine) was routinely grown at $37^{\circ} \mathrm{C}$ and $5 \%(\mathrm{v} / \mathrm{v}) \mathrm{CO}_{2}(21)$.

Cell morphology and viability measurements. AGS cells $\left(1 \times 10^{5}\right.$ cells/well) were seeded in 12-well plates with RPMI-1640 for $24 \mathrm{~h}$. NCTD at final concentrations of $10,15,20,25$ and $30 \mu \mathrm{M}$, or $0.1 \%$ DMSO as a vehicle control was added to each well and cells were cultered for $48 \mathrm{~h}$. Cells were then examined and photographed under phase-contrast microscopy at $\times 200$ for examination of cell morphological changes. Cells were harvested, counted and stained with PI $(5 \mu \mathrm{g} / \mathrm{ml})$ for total viable cell number measured by flow cytometry (BD Biosciences, FACSCalibur, San Jose, CA, USA) as previously described $(22,23)$.

Cell cycle and sub-G $G_{1}$ phase (apoptotic cell death) assays. Sub- $\mathrm{G}_{1}$ hypodiploid cells and cell-cycle distribution were quantified by flow cytometry as previously described (21). AGS cells $\left(1 \times 10^{5}\right.$ cells/well) in 12-well plates were incubated with $\operatorname{NCTD}(10,15$, 20,25 and $30 \mu \mathrm{M}$ ) for $48 \mathrm{~h}$ and were harvested, washed and fixed in $70 \%$ ethanol for $30 \mathrm{~min}$ at $37^{\circ} \mathrm{C}$ in the dark with a solution containing $50 \mathrm{mg} / \mathrm{ml}$ PI and $50 \mu \mathrm{g} / \mathrm{ml}$ RNase A. Cells were then analyzed by FACSCalibur flow cytometer (Becton Dickinson) and results were determined by CellQuest and ModFit computer programs as described previously (21).

Annexin V-FITC labeling. AGS cell apoptosis was measured by using the Annexin V/PI kit (BD Pharmingen, San Diego, CA, USA) as described previously (21). AGS cells $\left(1 \times 10^{5}\right.$ cells/well $)$ in 12-well plates were exposed to $30 \mu \mathrm{M}$ NCTD for 24 and $48 \mathrm{~h}$. Cells were washed twice with PBS solution and then resuspended cells in binding buffer [0.01 M Hepes/ $\mathrm{NaOH}(\mathrm{pH} 7.4), 0.14 \mathrm{M}$ $\mathrm{NaCl}, 2.5 \mathrm{mM} \mathrm{CaCl}_{2}$ ] and the following cells were stained with annexin V/PI (100 $\mu$ l binding buffer, $5 \mu \mathrm{l}$ annexin-V and $5 \mu \mathrm{PI})$ for $15 \mathrm{~min}$ at room temperature in the dark, and then were measured by flow cytometry (21).

Nuclear staining with 4,6-diamidino-2-phenylindole (DAPI). DAPI staining was carried out as previously described (21). AGS cells $\left(1 \times 10^{5}\right.$ cells/well $)$ were placed in 12 -well plates and cells were incubated with NCTD $(10,15,20,25$ and $30 \mu \mathrm{M})$ for 24 and $48 \mathrm{~h}$. Cells were fixed in $4 \%$ formaldehyde in PBS for $20 \mathrm{~min}$ at room temperature and were washed with PBS and stained with DAPI solution $(2 \mu \mathrm{g} / \mathrm{ml})$ (Santa Cruz Biotechnology, Inc., Dallas, TX, USA) at room temperature in the dark. Nuclear morphology was examined and photographed using a fluorescence microscope as described previously (21). 
A
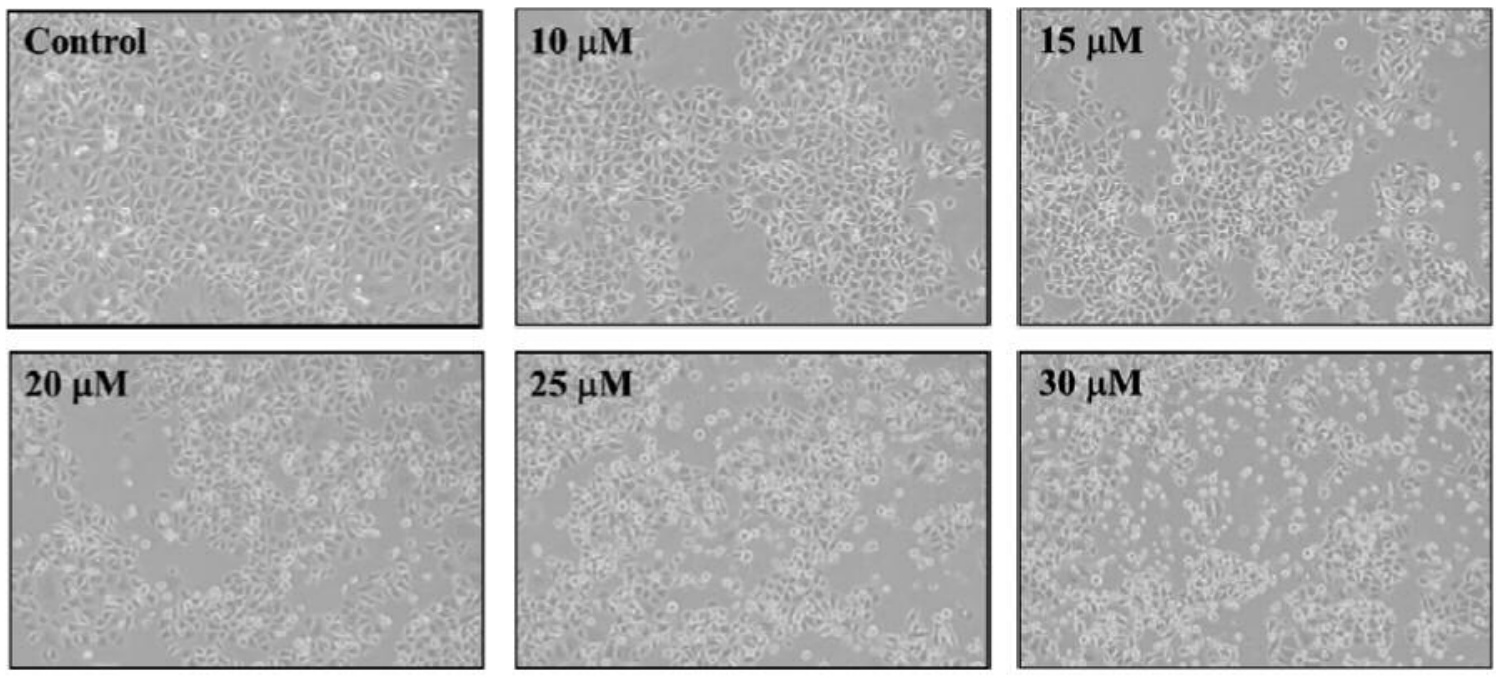

B

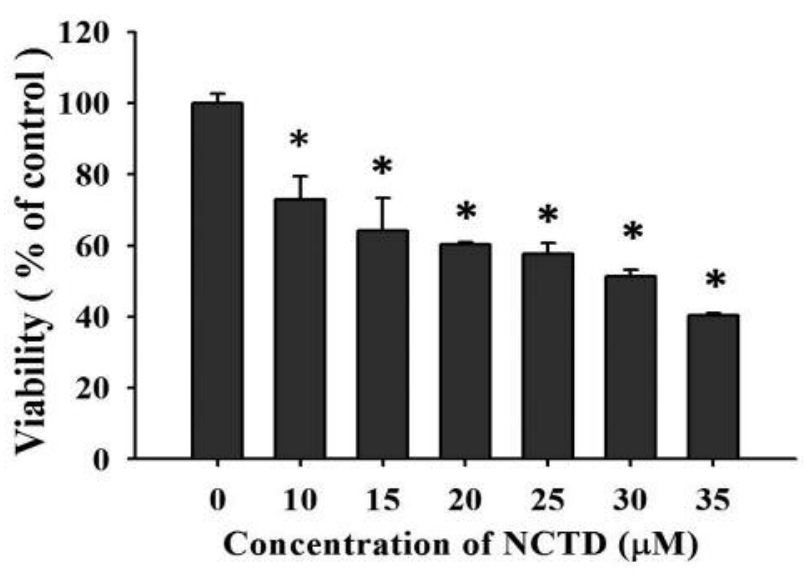

Measurements of $\mathrm{ROS}$, intracellular $\mathrm{Ca}^{2+}$ and mitochondrial membrane potential $(\Psi \mathrm{m})$. Flow cytometry was used for these experiments. AGS cells $\left(1 \times 10^{5}\right.$ cells/well $)$ in 12 -well plates were incubated with NCTD $(30 \mu \mathrm{M})$ for different time periods. At the end of incubation, cells were isolated and resuspended with $500 \mu \mathrm{l}$ of 2',7'-dichlorodihydrofluorescein diacetate (DCFH-DA) $(10 \mu \mathrm{M})$ for ROS measurement, or with $500 \mu \mathrm{l}$ of 3,3'-dihexyloxacarbocyanine iodide $\left(\mathrm{DiOC}_{6}\right)(4 \mu \mathrm{mol} / \mathrm{l})$ for $\Psi_{\mathrm{m}}$, or $500 \mu \mathrm{l}$ of Fluo3/acetoxymethyl ester (Fluo-3/AM) $(2.5 \mu \mathrm{g} / \mathrm{ml})$ for intracellular $\mathrm{Ca}^{2+}$ determination in the dark for $30 \mathrm{~min}$ and then cells were analyzed by flow cytometry as described previously $(24,25)$.

Measurements of caspase- 9 activity. The activity of caspase- 9 was measured by flow cytometric assay (21). AGS cells $\left(1 \times 10^{5}\right.$ cells/well) in 12-well plate were pretreated or with pan-caspase inhibitor (Z-VAD-FMK) for $3 \mathrm{~h}$ and with/without NCTD $(30 \mu \mathrm{M})$ for $0,6,12,24$ and $48 \mathrm{~h}$. After incubation, cells were collected, washed and re-suspended in $50 \mu \mathrm{l}$ of $10 \mu \mathrm{M}$ substrate solution containing CaspaLux9-M1D2 for caspase-9 activity measurement
Figure 1. Norcantharidin (NCTD) induced cell morphological changes and reduced the percentage of viable AGS cells. Cells were treated with NCTD for 48 h and the cells were examined and photographed for cell morphological changes by contrast-phase microscopy at $\times 200$ (A) and were collected for measurement of total number of viable cells $(B)$ by flow cytometry as described in the Materials and Methods Section. The results are shown as the mean $\pm S D(n=3)$. ${ }^{*} p<0.05$, Significantly different from the control as analyzed by Student's t-test.

before being incubated at $37^{\circ} \mathrm{C}$ for $60 \mathrm{~min}$. Cell samples were further analyzed by flow cytometry for caspase- 9 activity and total viable cells as described previously (26).

Western blot analysis. AGS cells $\left(1.5 \times 10^{6}\right.$ cells/dish) were placed in $10-\mathrm{cm}$ dish for $24 \mathrm{~h}$ then were incubated with NCTD $(30 \mu \mathrm{M})$ for 0 , $6,12,24$ and $48 \mathrm{~h}$. Cells were collected, lysed and total protein was determined by Bio-Rad protein assay kit (Bio-Rad Hercules, CA, USA) as described previously (21). Thirty micrograms of total cellular proteins were separated by sodium dodecyl sulfate polyacrylamide gel electrophoresis (12\% SDS-PAGE), transferred onto a polyvinylidene difluoride membranes (Millipore, Billerica, MA, USA) which were subsequently hybridized with the primary antibodies (1:1,000 dilution) and $\beta$-actin at $4^{\circ} \mathrm{C}$ overnight. After washing with PBS-Tween 20 buffer, the membrane was incubated with secondary antibody (1:5,000 dilution) anti-mouse IgG (Santa Cruz Biotechnology) for $1 \mathrm{~h}$ at room temperature. Protein bands were visualized by the enhanced chemiluminescence using ECL detection (GE Healthcare Bio-Sciences, Pittsburgh, PA, USA) (27, 28). 
A

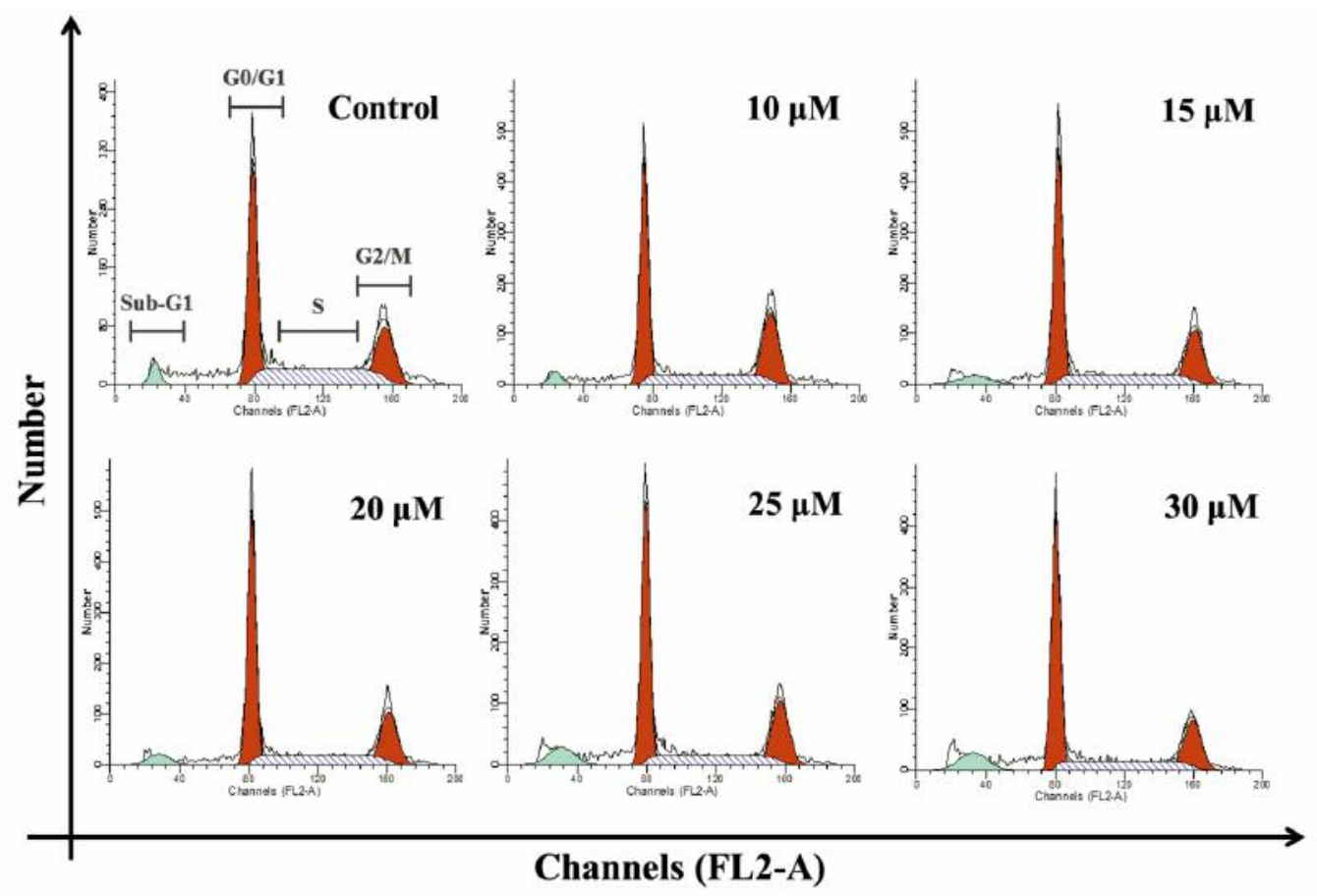

B

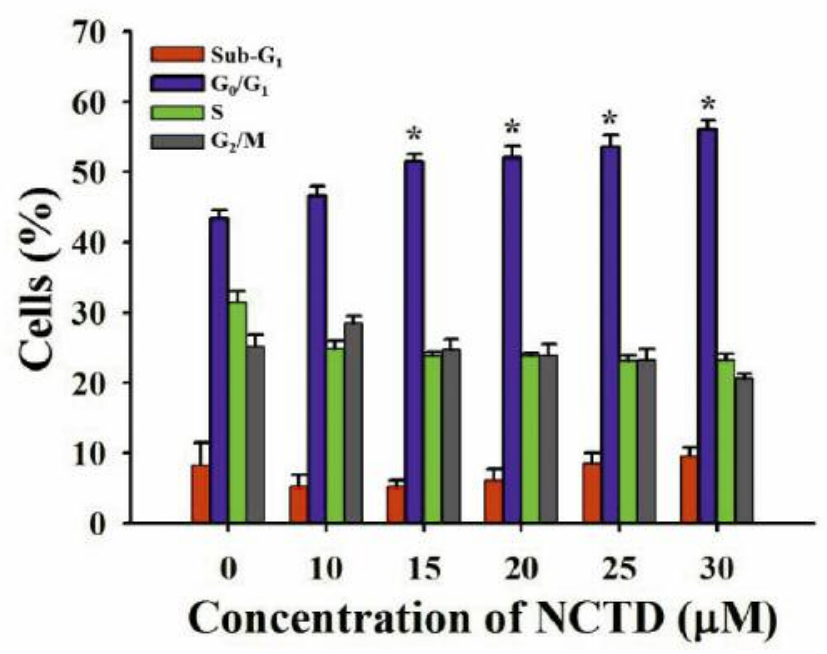

C
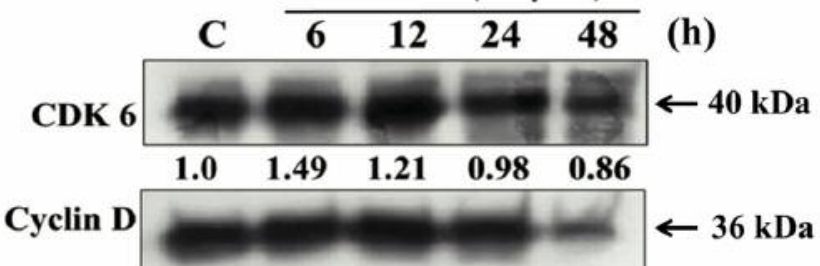

$\begin{array}{lllll}1.0 & 1.22 & 1.05 & 1.27 & 0.57\end{array}$
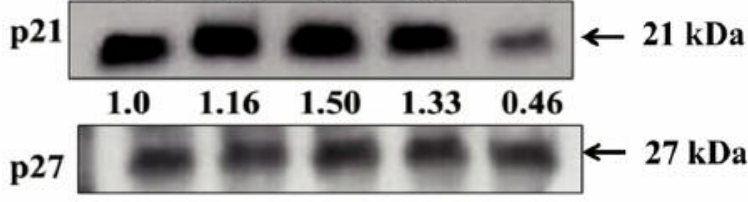

$\begin{array}{lllll}1.0 & 1.01 & 1.22 & 1.27 & 1.14\end{array}$

$\beta$-actin

Figure 2. Norcantharidin (NCTD) induced $G_{0} / G_{1}$ arrest and sub-G $G_{1}$ phase in AGS cells. AGS cells were treated with different concentrations of NCTD for $48 \mathrm{~h}$ or were treated with $30 \mu \mathrm{M}$ for different time periods. Cells were harvested for cell-cycle distribution by flow cytometric assay (A) and quantified by FACSCalibur flow cytometry (B). Protein expression was measured by western blotting as described in the Materials and Methods (C). The results are shown as the mean $\pm S D(n=3) .{ }^{*} p<0.05$, Significantly different from the control as analyzed by the Student's $t$-test. CDK6: Cyclin-dependent kinase 6.

Statistical analysis. The results are presented as the mean \pm standard deviation from three independent experiments. Significant differences among the groups were determined using the unpaired Student's $t$-test. The differences were considered statistically significant at $p<0.05$.

\section{Results}

NCTD induced cell morphological changes and reduced the cell viability of AGS cells. Cell morphology and viability 
A
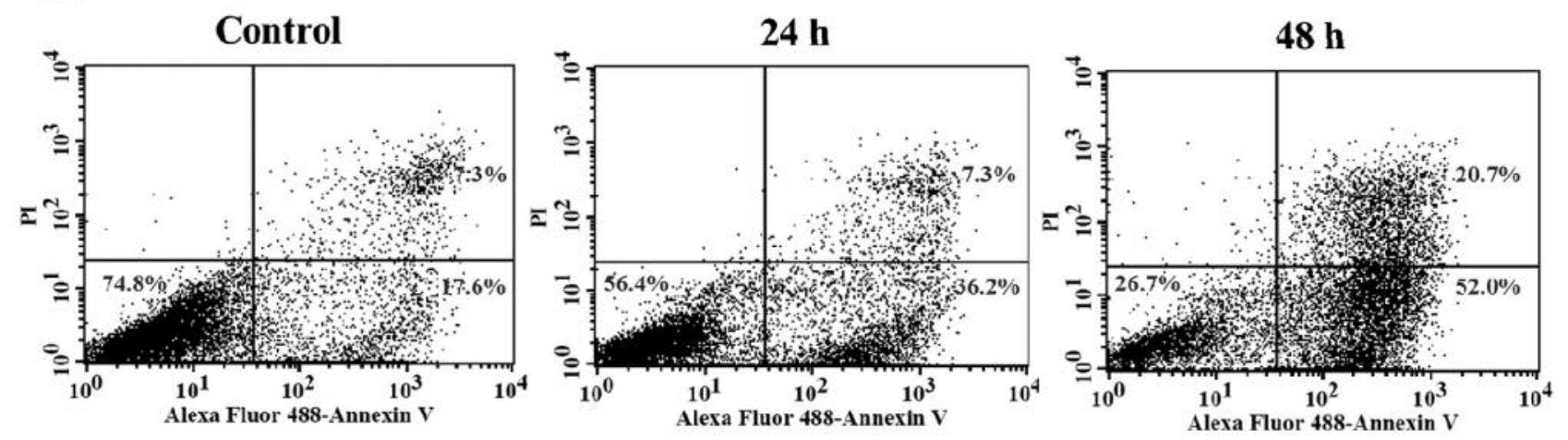

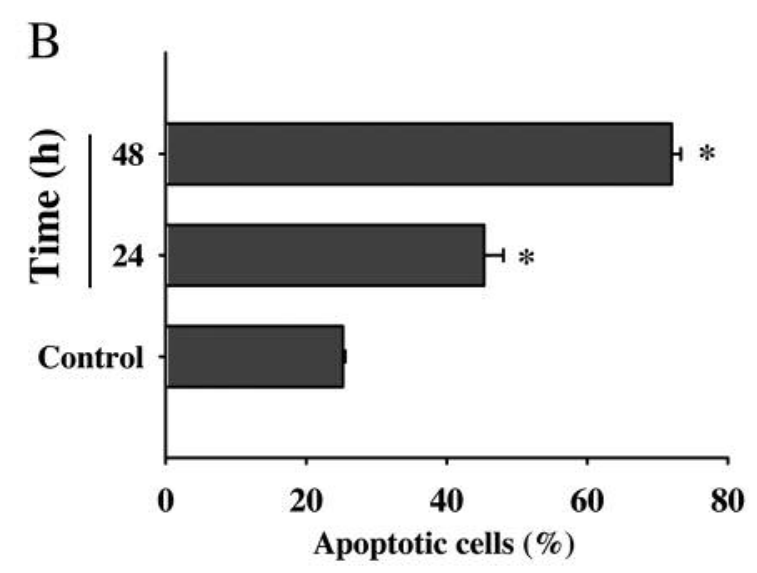

were performed by phase-contrast microscopy and flow cytometric assay, respectively. The results indicate that NCTD induced cell morphological changes (Figure 1A) and reduced total viable cell number (viability) of AGS cells dose-dependently (Figure 1B), with a half maximal inhibitory concentration $\left(\mathrm{IC}_{50}\right)$ of $30 \mu \mathrm{M}$ at $48 \mathrm{~h}$ treatment.

$N C T D$ induced $G_{0} / G_{1}$ arrest and sub-G $G_{1}$ phase in AGS cells. In order to understand whether NCTD reduced total viable cell number through cell-cycle arrest and cell apoptosis in AGS cells, AGS cells were treated with $0,10,15,20,25,30$ $\mu \mathrm{M}$ of NCTD for $48 \mathrm{~h}$ and were harvested for cell cycle distribution and sub- $\mathrm{G}_{1}$ phase assays. The results indicate that NCTD induced $G_{0} / G_{1}$ phase arrest (Figure 2A) and accumulation of cells in sub- $\mathrm{G}_{1}$ phase (apoptosis) (Figure 2B) and these effects were somewhat dose-dependent. For further investigating whether NCTD induced $G_{0} / G_{1}$ phase arrest through the effects of cell-cycle check point proteins, cells were harvested for western blotting. NCTD increased the protein expression of p27 at all examined time but p21 was increased from 6-24 h treatment. However, cyclin D and CDK6 decreased after $48 \mathrm{~h}$ treatment.
Figure 3. Norcantharidin (NCTD) induced apoptotic cell death of AGS cells. Cells were treated with 0 or $30 \mu M$ of NCTD for 24 and 48 then the cells were double stained with annexin V/propidium iodide (PI) and were analyzed for apoptotic cell death (A) and quantified by flow cytometric assay $(B)$ as described in the Materials and Methods section. The results are shown as the mean $\pm S D(n=3) .{ }^{*} p<0.05$, Significantly different from the control as analyzed by the Student's t-test.

NCTD induced apoptosis of AGS cells. For further understanding of whether the growth-inhibitory effect of NCTD is associated with cell apoptosis, annexin V/PI double staining of AGS cells by flow cytometric analyses were used. The number of apoptotic cells increased in a time-dependent manner after incubation with $30 \mu \mathrm{M}$ NCTD compared to the control group (Figure 3). These results indicate that inhibition of cell growth by NCTD was due to induction of cell apoptosis.

NCTD induce nuclear condensation in AGS cells. AGS cells were treated with $0,10,15,20,25$ and $30 \mu \mathrm{M}$ of NCTD for 24 and $48 \mathrm{~h}$ and then were stained with DAPI, examined and photographed by fluorescence microscopy, as shown in Figure 4A-C. Figure 4C indicates that longer treatment increased fluorescence of AGS cells when compared to control cells, as did increasing concentrations of NCTD. Increasing fluorescence reflects the increasing presence of nicked DNA and nuclear chromatin condensation in cells and these effects were also revealed to occur in a dose-dependent manner.

NCTD induced ROS and $\mathrm{Ca}^{2+}$ production and reduced the mitochondrial membrane potential $\left(\Psi_{m}\right)$ in AGS cells. AGS 


\section{A DAPI $24 \mathrm{~h}$}

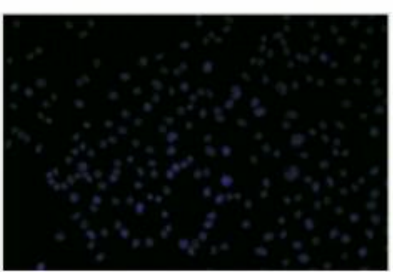

Control

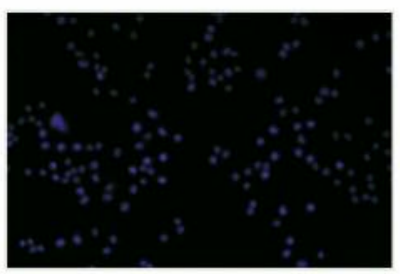

$20 \mu \mathrm{M}$

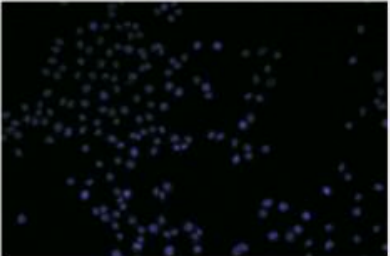

$10 \mu \mathrm{M}$

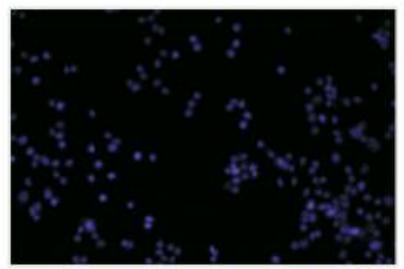

$25 \mu \mathrm{M}$

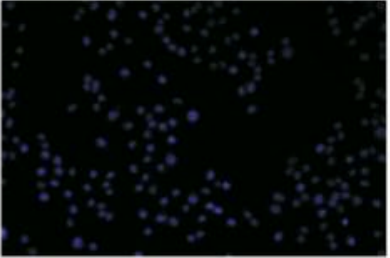

$15 \mu \mathrm{M}$

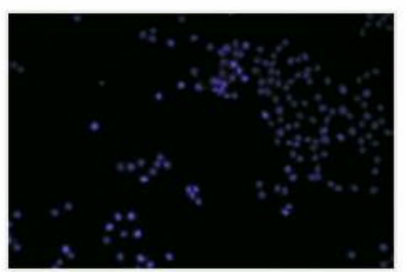

$30 \mu \mathrm{M}$

\section{B DAPI $48 \mathrm{~h}$}
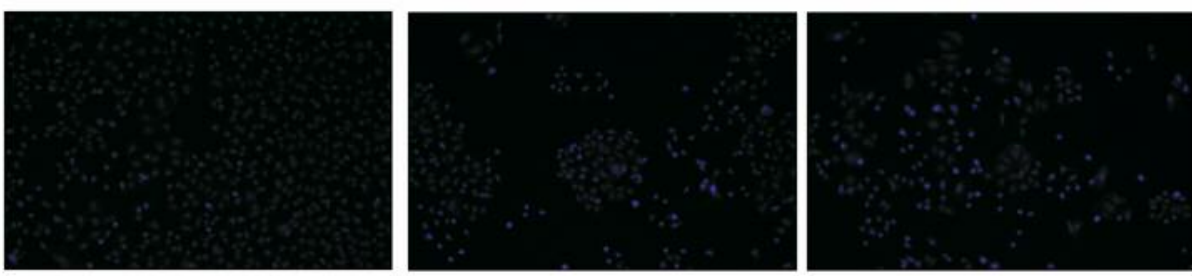

Control

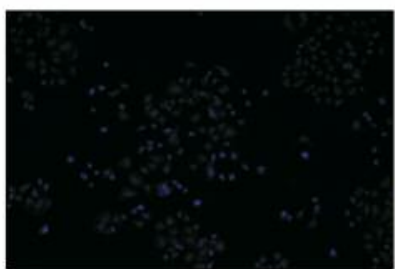

$10 \mu \mathrm{M}$

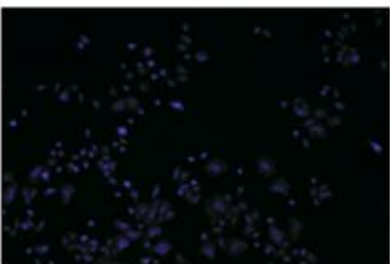

$25 \mu \mathrm{M}$

$15 \mu \mathrm{M}$

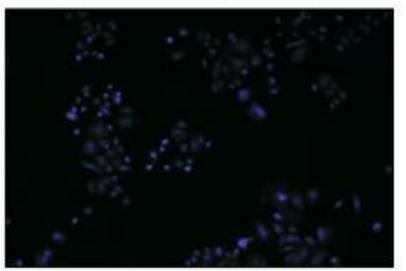

$30 \mu \mathrm{M}$

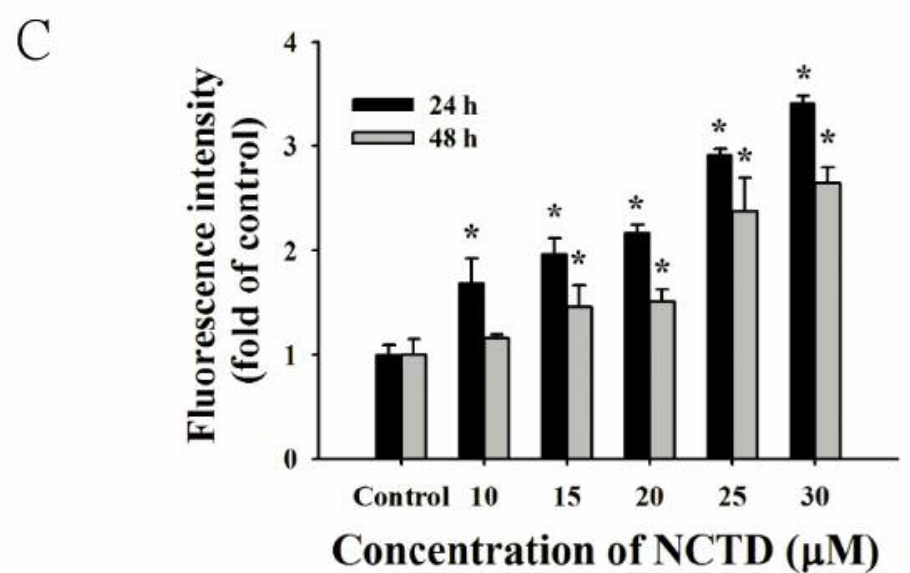

Figure 4. Norcantharidin (NCTD) induced nuclear chromatin condensation in AGS cells. Cells were treated with NCTD for 24 and 48 then were stained with 4',6-diamidino-2-phenylindole (DAPI) as described in the Materials and Methods section. The results are shown as the mean \pm SD $(n=3) .{ }^{*} p<0.05$, Significantly different from the control as analyzed by Student's $t$-test. 
A
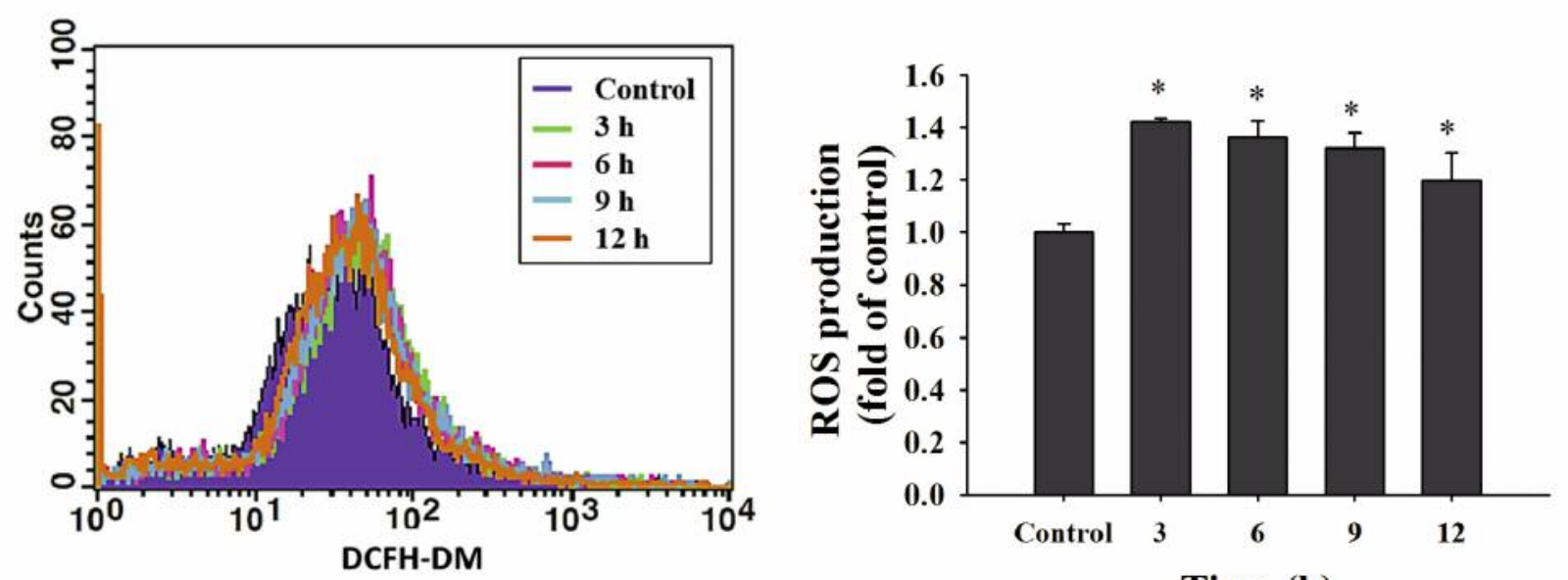

Time (h)

B
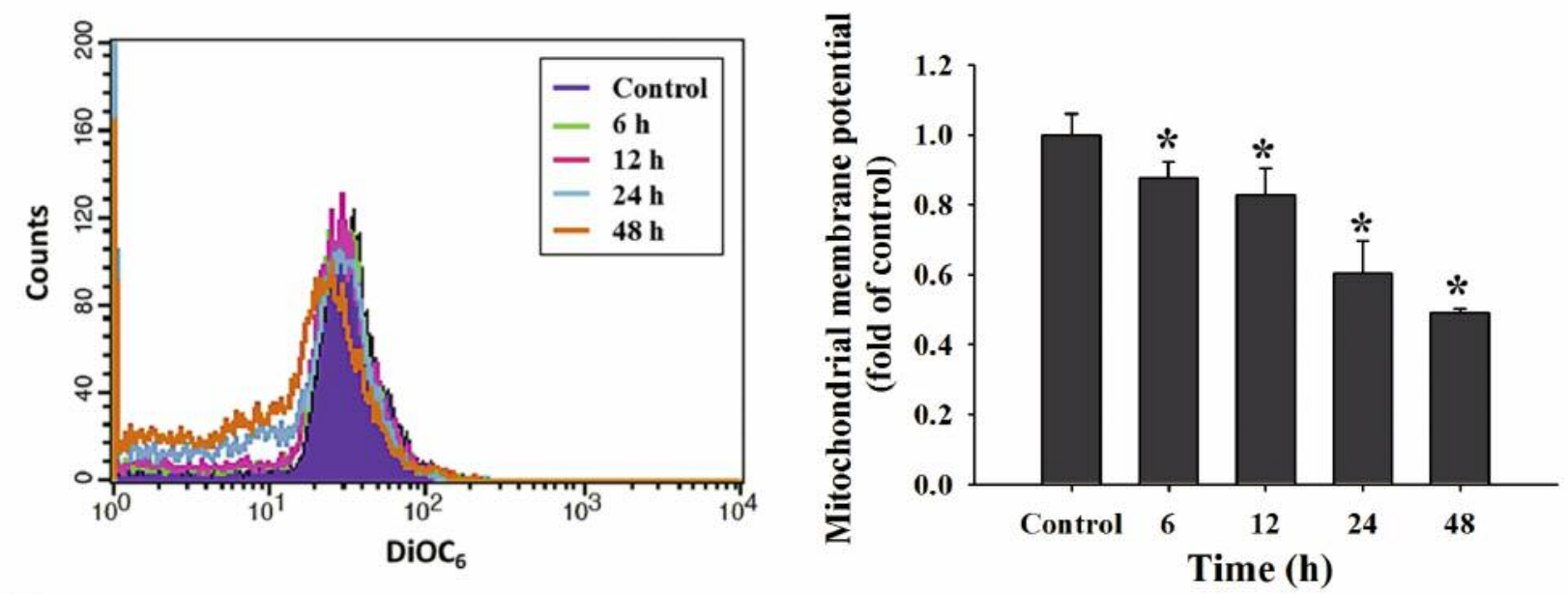

C
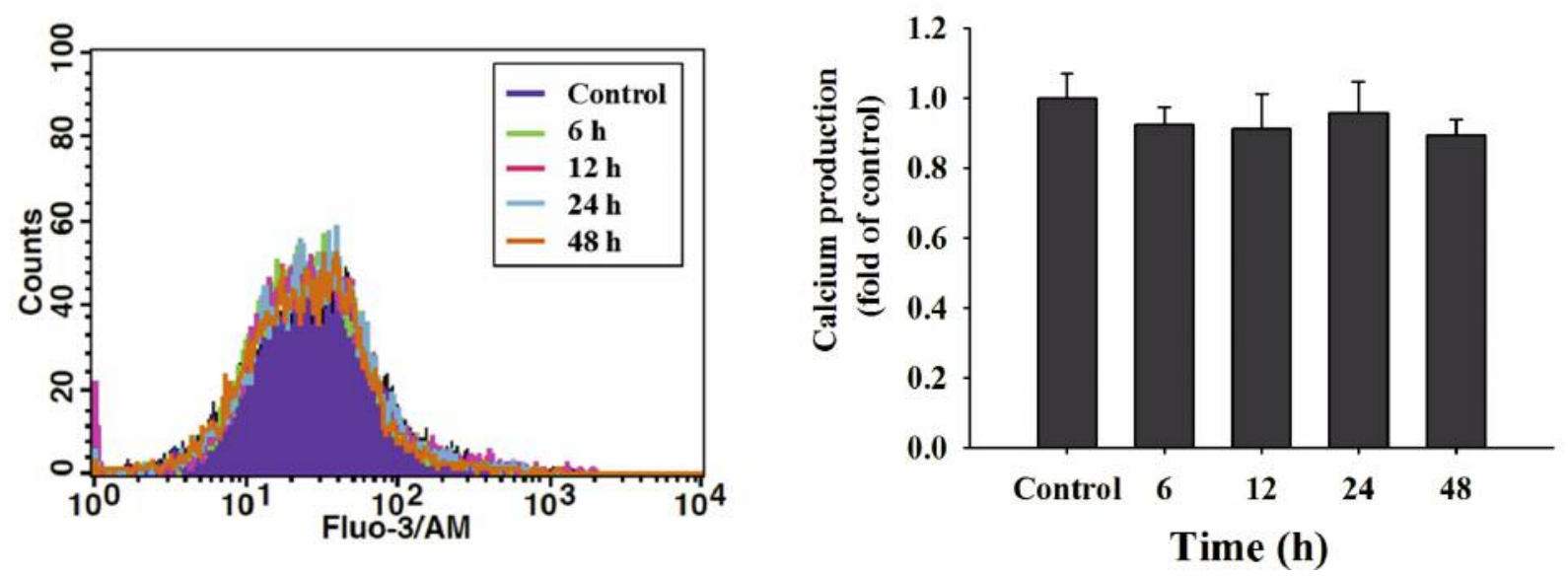

Figure 5. Norcantharidin (NCTD) induced reactive oxygen species (ROS) and $\mathrm{Ca}^{2+}$ production and reduced the mitochondrial membrane potential $(\Psi \mathrm{m})$ in AGS cells. Cells $\left(1 \times 10^{5}\right.$ cells/well $)$ were treated with $30 \mu \mathrm{M}$ of NCTD for different time periods. Cells were isolated and assayed for the production of $\operatorname{ROS}(A), \Delta \Psi_{m}$ measurement $(B)$ and $\mathrm{Ca}^{2+}(C)$ as described in the Materials and Methods section. The results are shown as the mean $\pm S D(n=3) . * p<0.05$, Significantly different from the control as analyzed by the Student's t-test. 

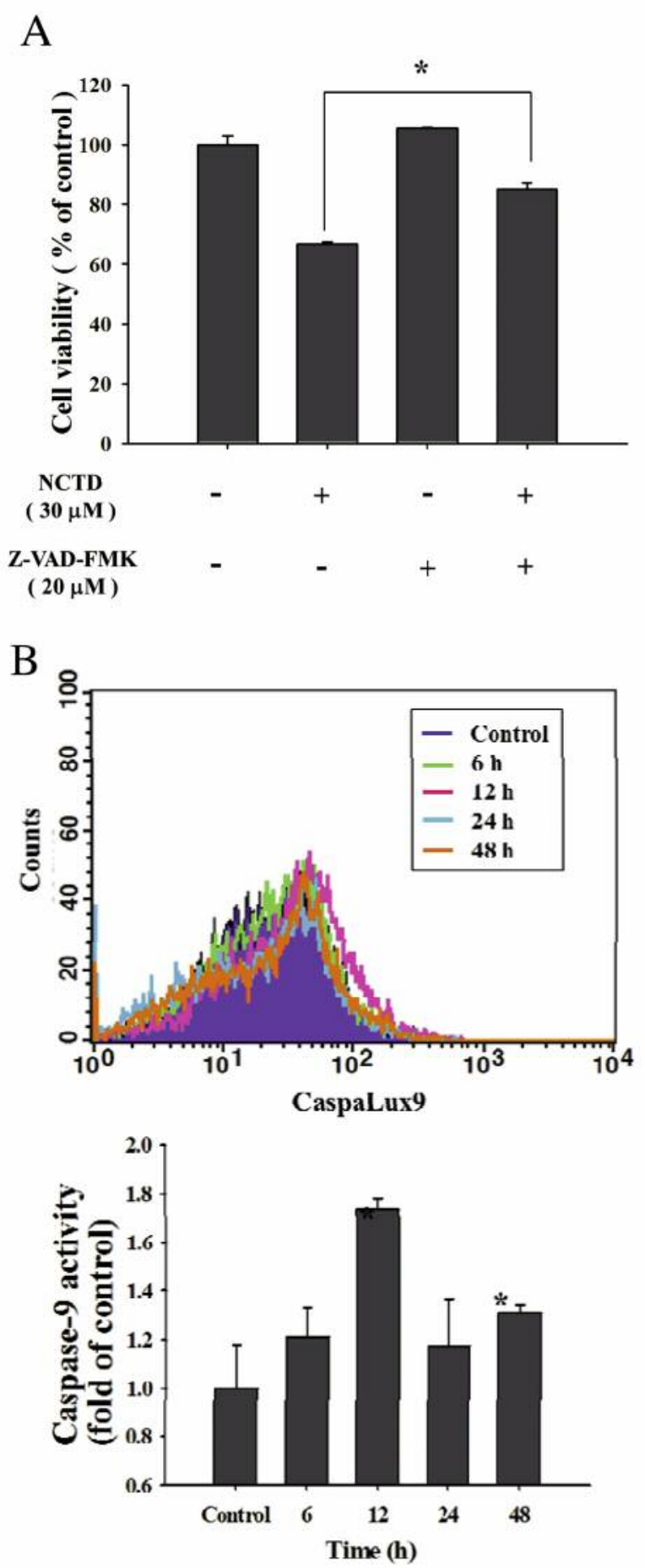

Figure 6. Measurement of caspase-9 activity. A: AGS cells $\left(2 \times 10^{5}\right.$ cells/well) in 12-well plates were pretreated or not with pan-caspase inhibitor (Z-VAD-FMK) and then treated with/without $30 \mu M$ of norcantharidin (NCTD) for $24 \mathrm{~h}$. Cell viabiliy was analyzed by flow cytometry as described in the Materials and Methods section. B: Cell were treated with $30 \mu M$ of NCTD for $0,6,12,24$ and $48 h$ then resuspended in $50 \mu \mathrm{l}$ of $10 \mu \mathrm{M}$ substrate solution containing CaspaLux9M1D2 for caspase-9 activity measurement by flow cytometry as described in the Materials and Methods Section.

cells were treated with $30 \mu \mathrm{M}$ of NCTD for different time periods and were harvested and analyzed by flow cytometric assay, as shown in Figure 5. NCTD increased ROS production from 3-12 $\mathrm{h}$ treatment (Figure 5A). NCTD reduced the mitochondrial membrane potential from $6 \mathrm{~h}$ up to $48 \mathrm{~h}$ treatment (Figure 5B), however, it did not significantly affect the level of $\mathrm{Ca}^{2+}$ production from 6-48 $\mathrm{h}$ treatment (Figure 5C) when compared to the control group. These results indicated that ROS, and $\Delta \Psi_{\mathrm{m}}$ are involved in NCTD-induced apoptosis of AGS cells in vitro.

NCTD increased the activity of caspase-9 in AGS cells. In order to investigate whether NCTD induced cell apoptosis involves caspase in AGS cells, cells were pretreated with pancaspase inhibitor (Z-VAD-FMK) for $3 \mathrm{~h}$ and then treated or not with $30 \mu \mathrm{M}$ of NCTD. Treatment with NCTD and pancaspase inhibitor increased the number of viable AGS cells compared to those only treated with NCTD (Figure 6A). Treatment of AGS cells with $30 \mu \mathrm{M}$ of NCTD for $6,12,24$ and $48 \mathrm{~h}$ led to increased caspase- 9 activity as shown in Figure 7A. These results indicate that NCTD induces AGS cell apoptosis through the activation of caspase-9 in vitro.

NCTD altered the expression of apoptosis-associated proteins in AGS cells. To investigate whether NCTD induced cell apoptosis involved changes in expression of apoptosisassociated proteins in AGS cells, cells were treated with $30 \mu \mathrm{M}$ of NCTD for $6,12,24$ and $48 \mathrm{~h}$ and proteins were examined by western blotting, as shown in Figure 7 . The results showed that NCTD significantly increased the expression of active form of caspase- $3,-9$ and -8 (Figure 7A), BAX, BID, BCL2, PARP, AIF, Endo G, and cytochrome c (Figure 7B), p53, XIAP and SMAC (Figure 7C), DR4, DR5, TRAIL and TNF $\alpha$ (Figure 7D) at all examined treatment times. However, caspase-12 and -4 (Figure 7E) were increased at 6-24 h treatment of NCTD. NCTD reduced the expression of caspase-7 (Figure 7A), Fas and FasL (Figure 7D), calpain-1 and GRP78 in AGS cells (Figure 7E).

\section{Discussion}

Numerous studies have demonstrated that NCTD induces cytotoxic effects on many human cancer cell lines through cell-cycle arrest and apoptosis, however, there is no available information to show that NCTD affects human gastric cancer AGS cells. In the present study, we investigated the cytotoxic effects of NCTD on human gastric cancer AGS cells in vitro. Herein, we found that NCTD induced $\mathrm{G}_{0} / \mathrm{G}_{1}$ phase arrest in AGS cells, which is in agreement with a report which showed that NCTD induced $\mathrm{G}_{0} / \mathrm{G}_{1}$ phase arrest at $25 \mu \mathrm{M}$. However, at high doses $(50 \mu \mathrm{M})$, it led to increase $\mathrm{G}_{2} / \mathrm{M}$ phase arrest (29). The mechanisms of NCTD-mediated regulation of cell cycle-related protein expression were investigated. Short 
A
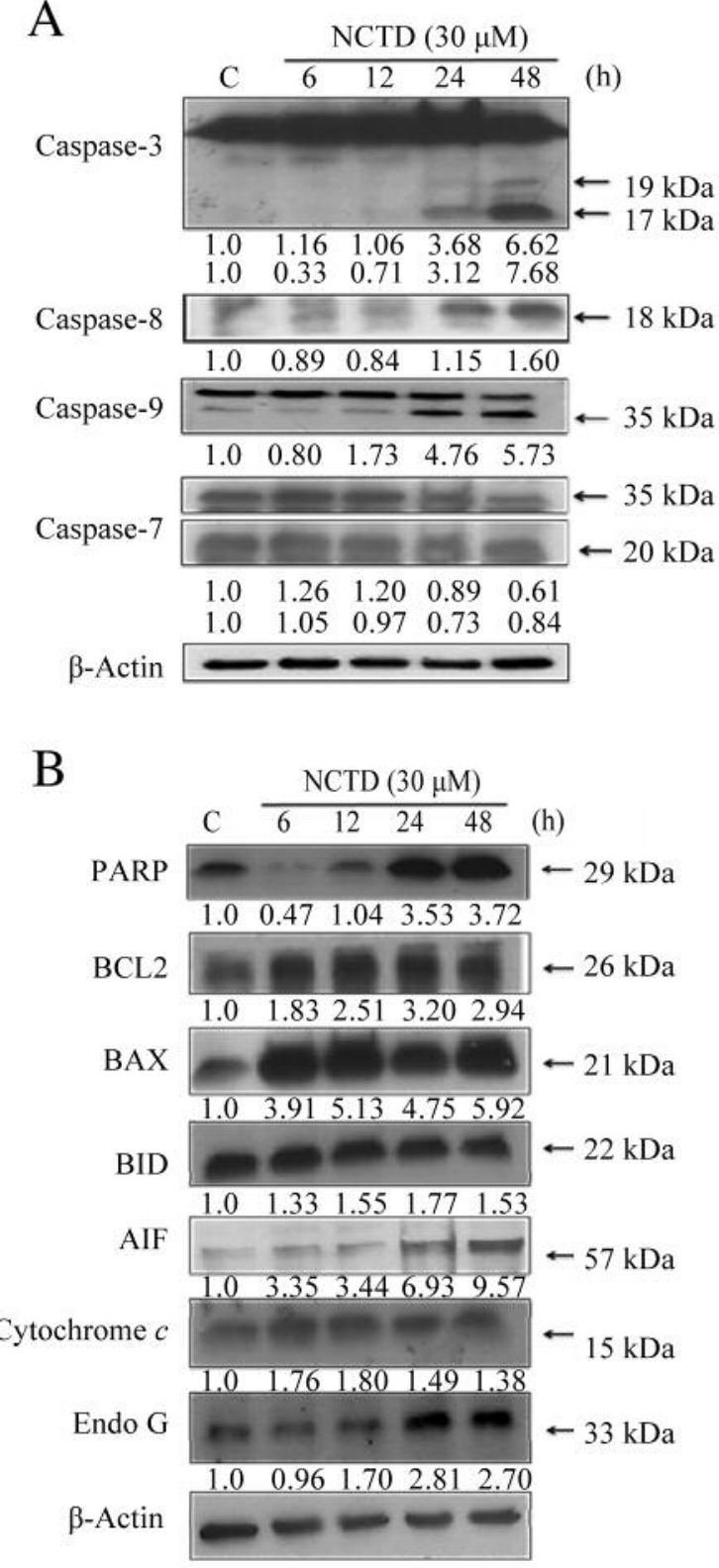

C

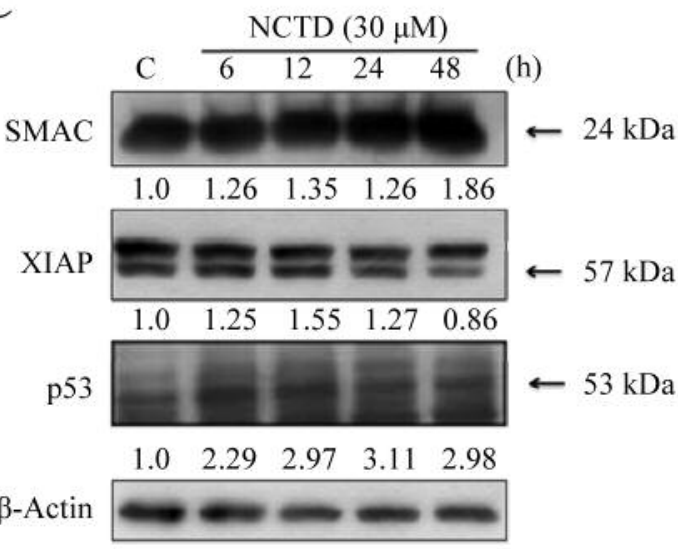

D
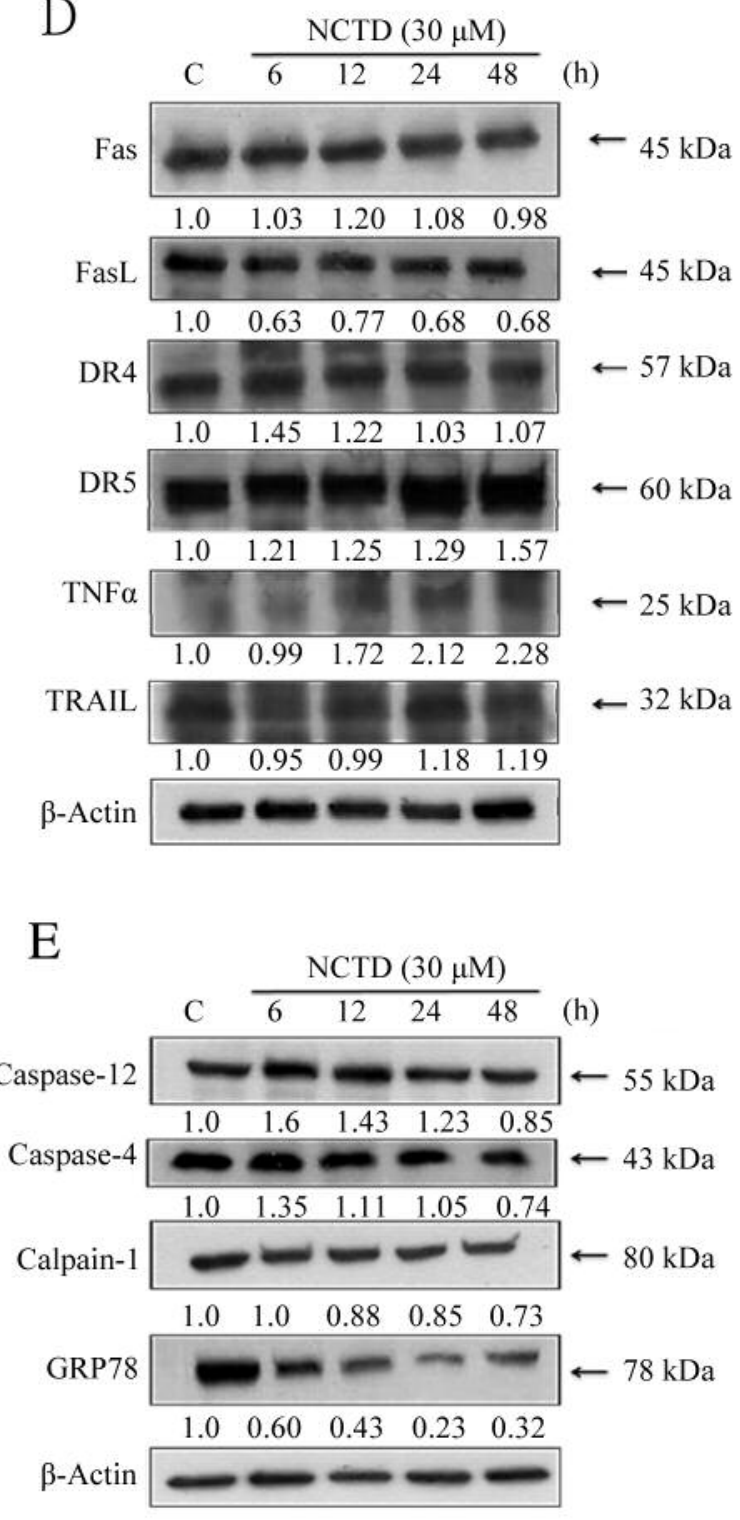

Figure 7. Norcantharidin (NCTD) affects expression of apoptosisassociated proteins in AGS cells. Cells were treated with $30 \mu M$ of NCTD for 0, 6, 12, 24 and $48 \mathrm{~h}$. Cells were then collected and total proteins were quantitated and apoptosis-associated proteins were examined by western blotting as described in the Materials and Methods section. A: Caspase-3, -8, -9 and -7; B: poly (ADP-ribose) polymerase (PARP), BCL2: B-cell lymphoma 2, BCL2-associated X protein (BAX), BH3 interacting-domain death agonist (BID), apoptosis-inducing factor (AIF), cytochrome $c$ and endonuclease $G$ (Endo $G$ ); $C$ : second mitochondrialderived activator of caspase (SMAC), $X$ chromosome-linked inhibitor of apoptosis protein (XIAP) and p53; D: Fas, FasL, death receptor 4 (DR4), DR5, tumor necrosis factor $\alpha(T N F \alpha)$ and TNF-related apoptosisinducing ligand (TRAIL); E: caspase-12 and -4, calpain-1 and glucoseregulated protein 78 (GRP78). 


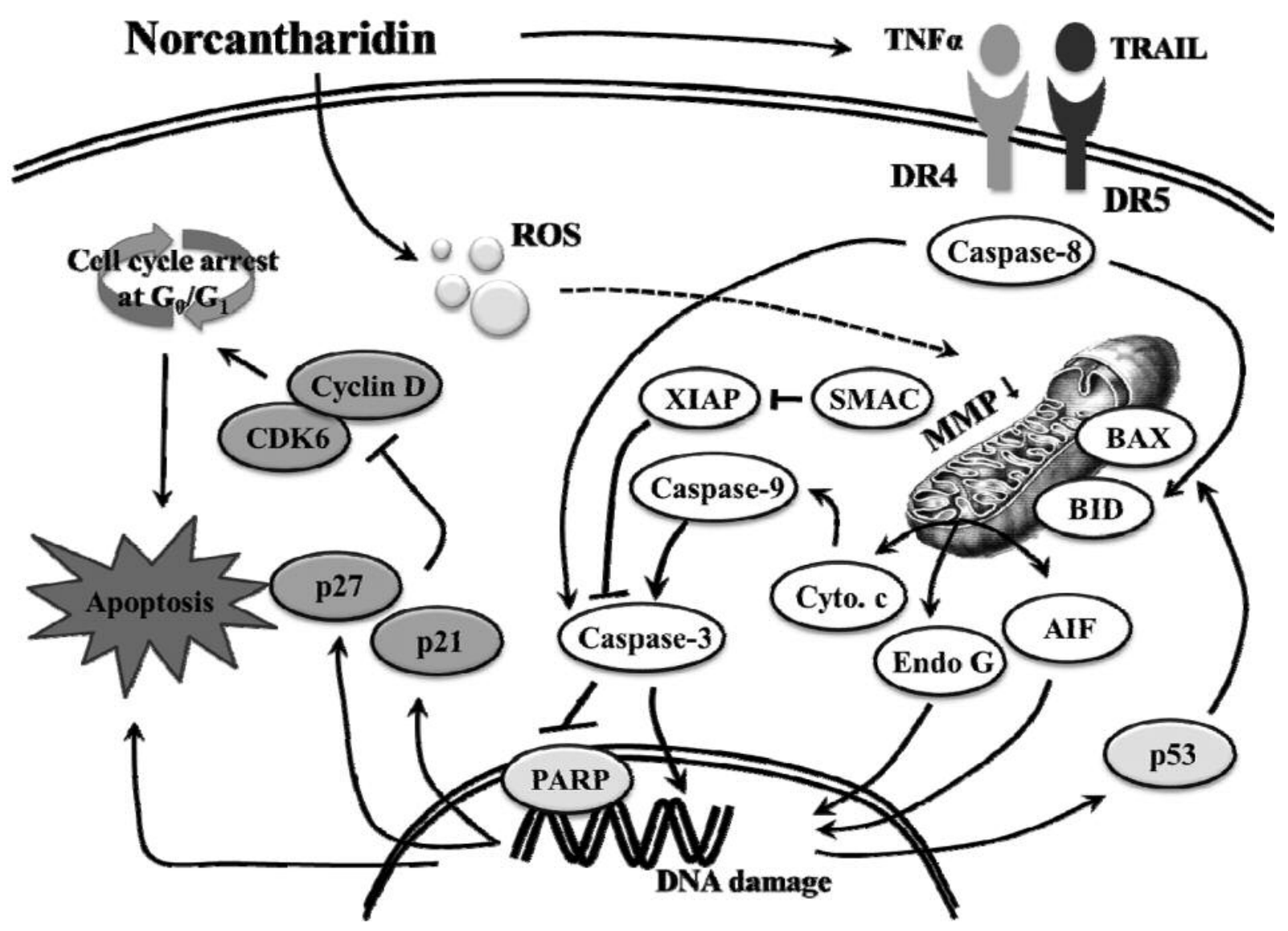

Figure 8. The proposed signaling pathways of norcantharidin (NCTD)-induced apoptosis in AGS cells. ROS: Reactive oxygen species; PARP: poly (ADP-ribose) polymerase; AIF: apoptosis-inducing factor; Endo G: endonuclease G; SMAC: second mitochondrial-derived activator of caspase; XIAP: X chromosome-linked inhibitor of apoptosis protein; DR/DR5: death receptor 4/5; TNF $\alpha$ : tumor necrosis factor $\alpha$; TRAIL: TNF-related apoptosis-inducing ligand; GRP78: glucose-regulated protein 78; CDK6: cyclin-dependent kinase 6; BAX: BCL2-associated X protein; BID: BH3 interacting-domain death agonist; MMP: matrix metalloproteinase.

NCTD treatment led to increased p21 and p27 but inhibited expression of cyclin D and CDK6 in AGS cells. Other studies have shown that the functional property of the phosphorylation of $\mathrm{p} 21^{\mathrm{CIP} 1 / \mathrm{WAF} 1}$ upon NCTD treatment is still unclear (30). The possible role of $\mathrm{p} 21^{\mathrm{CIP} 1 / \mathrm{WAF} 1}$ in $\mathrm{G}_{0} / \mathrm{G}_{1}$ phase in AGS cells needs further investigation.

Sub- $\mathrm{G}_{1}$ phase population of AGS cells was observed after exposed to different concentrations of NCTD. The sub-G1 phase is recognized to be one of the hallmarks of cell apoptosis $(31,32)$. Annexin V/PI double staining confirmed here that NCTD induced cell apoptosis of AGS cells; NCTD has been shown to induce apoptosis of multiple types of cancer cells $(10,15,33,34)$. We also used DAPI staining to show NCTD induced chromatin condensation to show NCTD induce DNA damaged, in agreement with a report on TSGH 8301 human urinary bladder carcinoma cells (13). The balance between the accumulation of ROS and the antioxidant system are partially involved in cell-cycle progression, and interference during cell division may lead to abnormal cell proliferation (35). Our results indicated that NCTD increased the production of ROS in AGS cells. Oxidative stress maybe caused by the overproduction of ROS in cells or tissues and it can be an important mediator of cell structure damages and initiation of cancer development (36).

Numerous evidence has indicated that mitochondria dysfunction reduces $\Psi \mathrm{m}$, associated with cell apoptosis (3739). Induction of cell apoptosis through reduction of $\Psi_{\mathrm{m}}$ by some anticancer drugs is mediated through the intrinsic signaling pathway $(40,41)$. Herein, NCTD significantly reduced the $\Delta \Psi \mathrm{m}$ in AGS cells and these effects were timedependent. These observations are in agreement with other reports that NCTD induced cancer cell apoptosis is associated with mitochondrial dysfunction $(10,42)$. Furthermore, NCTD 
was shown to induce cell apoptosis through ROS-mediated mitochondrial dysfunction and energy depletion in DU145 prostate cancer cells (10). Therefore, we investigated expression of proteins associated with cell apoptosis which is also related to $\Delta \Psi \mathrm{m}$ in AGS cells after exposure to NCTD in vitro. NCTD increased expression of pro-apoptotic proteins such as BAX and BID and increased that of the active form of caspase-9, cytochrome $c$, AIF and Endo G in AGS cells. Based on these findings, we suggest that NCTD induced cell apoptosis of AGS through the mitochondria-dependent pathway by increased ROS production, loss of $\Delta \Psi \mathrm{m}$, increased expression of apoptosis-associated proteins, leading to cell apoptosis.

Numerous studies have shown that the activation of the caspase cascade is associated with cell apoptosis $(43,44)$. We used flow cytometric assay and found that NCTD increased activity of caspase- 9 . These results were also confirmed by western blotting. These results suggest that NCTD may induce apoptosis mainly through the activation of caspase-3 and caspase-9. Results from western blotting also showed that NCTD significantly increased the protein expressions of DR4 and DR5 and TNF $\alpha$ in AGS cells, indicating that NCTD induced cell apoptosis of AGS cells may be partially through these signaling pathways.

The present study indicated that NCTD reduced AGS human gastric cancer cell numbers by inducing $G_{0} / G_{1}$ phase arrest and cellular apoptosis in vitro (Figure 8). The induction of apoptosis by NCTD was associated with caspase- and mitochondria-dependent pathways and accompanied by the releases of cytochrome c, AIF and Endo G.

\section{Conflicts of Interest}

The Authors report no conflict of interest in regard to this study.

\section{Acknowledgements}

This work was supported by the grants CMU103-ASIA-01 from China Medical University, Taichung.

\section{References}

1 Ministry of Health and Welfare: The cancer mortality report of the Department of Health, Taiwan. 2014.

2 Corso G, Seruca R and Roviello F: Gastric cancer carcinogenesis and tumor progression. Ann Ital Chir 83: 172176, 2012.

3 Liu Y, Yoshimura K, Yamaguchi N, Shinmura K, Yokota J and Katai H: Causation of Borrmann type 4 gastric cancer: heritable factors or environmental factors? Gastric Cancer 6: 17-23, 2003.

4 Oikawa Y, Matsuda E, Nishii T, Ishida Y and Kawaichi M: Down-regulation of CIBZ, a novel substrate of caspase-3, induces apoptosis. J Biol Chem 283: 14242-14247, 2008.

5 Elmore S: Apoptosis: a review of programmed cell death. Toxicol Pathol 35: 495-516, 2007.
6 Kim JH, Choi YW, Park C, Jin CY, Lee YJ, Park DJ, Kim SG, Kim GY, Choi IW, Hwang WD, Jeong YK, Kim SK and Choi YH: Apoptosis induction of human leukemia U937 cells by gomisin N, a dibenzocyclooctadiene lignan, isolated from Schizandra chinensis Baill. Food Chem Toxicol 48: 807-813, 2010.

7 Fulda S, Galluzzi L and Kroemer G: Targeting mitochondria for cancer therapy. Nat Rev Drug Discov 9: 447-464, 2010.

8 Zhou Q, Li Y, Jin J, Lang L, Zhu Z, Fang W and Chen X: Lx232c, a novel taxane derivative, exerts anti-resistance activity by initiating intrinsic apoptosis pathway in vitro and inhibits the growth of resistant tumor in vivo. Biol Pharm Bull 35: 21702179, 2012.

9 Pistritto G, Trisciuoglio D, Ceci C, Garufi A and D'Orazi G: Apoptosis as anticancer mechanism: function and dysfunction of its modulators and targeted therapeutic strategies. Aging 8: 603619,2016

10 Shen B, He PJ and Shao CL: Norcantharidin induced DU145 cell apoptosis through ROS-mediated mitochondrial dysfunction and energy depletion. PLoS One 8: e84610, 2013.

11 Chang C, Zhu Y, Tang X and Tao W: The anti-proliferative effects of norcantharidin on human HepG2 cells in cell culture. Mol Biol Rep 38: 163-169, 2011.

12 Cimmino F, Scoppettuolo MN, Carotenuto M, De Antonellis P, Dato VD, De Vita G and Zollo M: Norcantharidin impairs medulloblastoma growth by inhibition of Wnt/beta-catenin signaling. J Neurooncol 106: 59-70, 2012.

13 Yu CC, Ko FY, Yu CS, Lin CC, Huang YP, Yang JS, Lin JP and Chung JG: Norcantharidin triggers cell death and DNA damage through S-phase arrest and ROS-modulated apoptotic pathways in TSGH 8301 human urinary bladder carcinoma cells. Int J Oncol 41: 1050-1060, 2012.

14 Yi SN, Wass J, Vincent P and Iland H: Inhibitory effect of norcantharidin on K562 human myeloid leukemia cells in vitro. Leuk Res 15: 883-886, 1991.

15 An WW, Wang MW, Tashiro S, Onodera S and Ikejima T: Norcantharidin induces human melanoma A375-S2 cell apoptosis through mitochondrial and caspase pathways. J Korean Med Sci 19: 560-566, 2004.

16 Fan YZ, Fu JY, Zhao ZM and Chen CQ: Inhibitory effect of norcantharidin on the growth of human gallbladder carcinoma GBC-SD cells in vitro. Hepatobiliary Pancreat Dis Int 6: 72-80, 2007.

17 Zheng J, Du W, Song LJ, Zhang R, Sun LG, Chen FG and Wei XT: Norcantharidin induces growth inhibition and apoptosis of glioma cells by blocking the Raf/MEK/ERK pathway. World J Surg Oncol 12: 207, 2014.

18 Wang H, Sun W, Zhang WZ, Ge CY, Zhang JT, Liu ZY and Fan YZ: Inhibition of tumor vasculogenic mimicry and prolongation of host survival in highly aggressive gallbladder cancers by norcantharidin via blocking the ephrin type a receptor $2 /$ focal adhesion kinase/paxillin signaling pathway. PLoS One 9: e96982, 2014.

19 Yuan X, Chen Y, Li X, Zhang G, Jin D, Zhao H, Su Z and Fan Y: Norcantharidin inhibits lymphangiogenesis by down-regulating the expression of VEGF-C and VEGF-D in human dermal lymphatic endothelial cells in vitro. Pharmacology 95: 1-9, 2015.

20 Ren J, Li G, Zhao W, Lin L and Ye T: Norcantharidin combined with ABT-737 for hepatocellular carcinoma: Therapeutic effects and molecular mechanisms. World J Gastroenterol 22: 39623968, 2016. 
21 Chiang JH, Yang JS, Ma CY, Yang MD, Huang HY, Hsia TC, Kuo HM, Wu PP, Lee TH and Chung JG: Danthron, an anthraquinone derivative, induces DNA damage and caspase cascades-mediated apoptosis in SNU-1 human gastric cancer cells through mitochondrial permeability transition pores and Bax-triggered pathways. Chem Res Toxicol 24: 20-29, 2011.

22 Chiu YJ, Hour MJ, Lu CC, Chung JG, Kuo SC, Huang WW, Chen HJ, Jin YA and Yang JS: Novel quinazoline HMJ-30 induces U-2 OS human osteogenic sarcoma cell apoptosis through induction of oxidative stress and up-regulation of ATM/p53 signaling pathway. J Orthop Res 29: 1448-1456, 2011.

23 Huang WW, Chiu YJ, Fan MJ, Lu HF, Yeh HF, Li KH, Chen PY, Chung JG and Yang JS: Kaempferol induced apoptosis via endoplasmic reticulum stress and mitochondria-dependent pathway in human osteosarcoma U-2 OS cells. Mol Nutr Food Res 54: 1585-1595, 2010.

24 Lu CC, Yang JS, Chiang JH, Hour MJ, Lin KL, Lin JJ, Huang WW, Tsuzuki M, Lee TH and Chung JG: Novel quinazolinone MJ-29 triggers endoplasmic reticulum stress and intrinsic apoptosis in murine leukemia WEHI-3 cells and inhibits leukemic mice. PLoS One 7: e36831, 2012.

25 Huang WW, Yang JS, Lin MW, Chen PY, Chiou SM, Chueh FS, Lan YH, Pai SJ, Tsuzuki M, Ho WJ and Chung JG: Cucurbitacin E induces G(2)/M Phase arrest through STAT3/p53/p21 signaling and provokes apoptosis via Fas/CD95 and mitochondriadependent pathways in human bladder cancer T24 cells. Evid Based Complement Alternat Med 2012: 952762, 2012.

26 Yang JS, Hour MJ, Huang WW, Lin KL, Kuo SC and Chung JG: MJ-29 inhibits tubulin polymerization, induces mitotic arrest, and triggers apoptosis via cyclin-dependent kinase 1-mediated BCL-2 phosphorylation in human leukemia U937 cells. J Pharmacol Exp Ther 334: 477-488, 2010.

27 Liao CL, Lai KC, Huang AC, Yang JS, Lin JJ, Wu SH, Gibson Wood W, Lin JG and Chung JG: Gallic acid inhibits migration and invasion in human osteosarcoma U-2 OS cells through suppressing the matrix metalloproteinase-2/-9, protein kinase B (PKB) and PKC signaling pathways. Food Chem Toxicol 50: 1734-1740, 2012.

28 Chueh FS, Chen YY, Huang AC, Ho HC, Liao CL, Yang JS, Kuo CL and Chung JG: Bufalin-inhibited migration and invasion in human osteosarcoma U-2 OS cells is carried out by suppression of the matrix metalloproteinase-2, ERK, and JNK signaling pathways. Environ Toxicol 2011.

29 Yeh CH, Yang YY, Huang YF, Chow KC and Chen MF: Induction of apoptosis in human Hep3B hepatoma cells by norcantharidin through a p53 independent pathway via TRAIL/DR5 signal transduction. Chin J Integr Med 18: 676-682, 2012.

30 Liao HF, Chen YJ, Chou CH, Wang FW and Kuo CD: Norcantharidin induces cell-cycle arrest and inhibits progression of human leukemic Jurkat T-cells through mitogen-activated protein kinase-mediated regulation of interleukin-2 production. Toxicol In Vitro 25: 206-212, 2011.

31 Shang HS, Shih YL, Lee CH, Hsueh SC, Liu JY, Liao NC, Chen YL, Huang YP, Lu HF and Chung JG: Sulforaphane-induced apoptosis in human leukemia HL-60 cells through extrinsic and intrinsic signal pathways and altering associated genes expression assayed by cDNA microarray. Environ Toxicol 2016, doi:10.1002/tox.22237.

32 Thiyagarajan V, Tsai MJ and Weng CF: Antroquinonol targets FAK-signaling pathway suppressed cell migration, invasion, and tumor growth of C6 glioma. PLoS One 10: e0141285, 2015.
33 Chen YN, Chen JC, Yin SC, Wang GS, Tsauer W, Hsu SF and Hsu SL: Effector mechanisms of norcantharidin-induced mitotic arrest and apoptosis in human hepatoma cells. Int J Cancer 100: 158-165, 2002.

34 Han Z, Li B, Wang J, Zhang X, Li Z, Dai L, Cao M and Jiang J: Norcantharidin inhibits SK-N-SH neuroblastoma cell growth by induction of autophagy and apoptosis. Technol Cancer Res Treat 2016, doi: 10.1177/1533034615624583

35 Sarsour EH, Kumar MG, Chaudhuri L, Kalen AL and Goswami PC: Redox control of the cell cycle in health and disease. Antioxid Redox Signal 11: 2985-3011, 2009.

36 Gülçin I, Uğuz MT, Oktay M, Beydemir Ş and Küfrevioğlu Öİ: Evaluation of the antioxidant and antimicrobial activities of clary sage (Salvia sclarea L.). Turk J Agric Forestry 28: 25-33, 2004.

37 Shiue YW, Lu CC, Hsiao YP, Liao CL, Lin JP, Lai KC, Yu CC, Huang YP, Ho HC and Chung JG: Casticin induced apoptosis in A375.S2 human melanoma cells through the inhibition of NF$[\varkappa] \mathrm{B}$ and mitochondria-dependent pathways in vitro and inhibited human melanoma xenografts in a mouse model in vivo. Am J Chin Med 44: 637-661, 2016.

38 Suwanjang W, Abramov AY, Charngkaew K, Govitrapong P and Chetsawang B: Melatonin prevents cytosolic calcium overload, mitochondrial damage and cell death due to toxically high doses of dexamethasone-induced oxidative stress in human neuroblastoma SH-SY5Y cells. Neurochem Int 97: 34-41, 2016.

39 Wang XD, Li CY, Jiang MM, Li D, Wen P, Song X, Chen JD, Guo LX, Hu XP, Li GQ, Zhang J, Wang CH and He ZD: Induction of apoptosis in human leukemia cells through an intrinsic pathway by cathachunine, a unique alkaloid isolated from Catharanthus roseus. Phytomedicine 23: 641-653, 2016.

40 Mohan S, Abdelwahab SI, Kamalidehghan B, Syam S, May KS, Harmal NS, Shafifiyaz N, Hadi AH, Hashim NM, Rahmani M, Taha MM, Cheah SC and Zajmi A: Involvement of NF-kappaB and BCL2/BAX signaling pathways in the apoptosis of MCF7 cells induced by a xanthone compound Pyranocycloartobiloxanthone A. Phytomedicine 19: 1007-1015, 2012.

41 Simon HU, Haj-Yehia A and Levi-Schaffer F: Role of reactive oxygen species (ROS) in apoptosis induction. Apoptosis 5: 415418, 2000.

42 Dong X, Li JC, Jiang YY, Xia MY, Tashiro S, Onodera S and Ikejima T: p38-NF-kappaB-promoted mitochondria-associated apoptosis and $\mathrm{G}_{2} / \mathrm{M}$ cell-cycle arrest in norcantharidin-treated HeLa cells. J Asian Nat Prod Res 14: 1008-1019, 2012.

$43 \mathrm{Li}$ LK, Rola AS, Kaid FA, Ali AM and Alabsi AM: Goniothalamin induces cell cycle arrest and apoptosis in H400 human oral squamous cell carcinoma: A caspase-dependent mitochondrial-mediated pathway with down-regulation of NFkappabeta. Arch Oral Biol 64: 28-38, 2016.

44 Rosebeck S, Alonge MM, Kandarpa M, Mayampurath A, Volchenboum SL, Jasielec J, Dytfeld D, Maxwell SP, Kraftson SJ, McCauley D, Shacham S, Kauffman M and Jakubowiak AJ: Synergistic myeloma cell death via novel intracellular activation of caspase-10-dependent apoptosis by carfilzomib and selinexor. Mol Cancer Ther 15: 60-71, 2016. 